\title{
Investigation causes of pavement structure failure using new AASHTO mechanistic-empirical procedures for optimization roads performance in different climatic condition of Iran
}

\author{
Maliheh Behnam $^{* 1}$, Hedyeh Khojasteh ${ }^{2}$, Mir mohammad Seyyed Hashemi ${ }^{1}$, Mehdi Javid ${ }^{3}$ \\ Received:20.08.2015 \\ Revised:25.09.2015 \\ Accepted: 30.10.2015
}

\begin{abstract}
In recent years, procedure of AASHTO (American Association State Highway and Transportation Officials) Guide for Design of Pavement Structures distanced from first empirical procedure and advanced toward mechanisticempirical procedures. "Guide for Mechanistic-Empirical Design of New and Rehabilitated Pavement Structures" in 2004 and its attached software M-EPDG is the result of this new procedure that AASHTO presented it through projects NCHRP 1-37 A and NCHRP 1-40 B with cooperation of NCHRP (National Cooperative Highway Research Program) and FHWA (Federal Highway Administration) institutions. In this paper, requireddata for software analyzing of three real pavement structures pieces collected from three different climatic areas and pavement structures modeled in software by entering data into software. Modeled sections by this software were analyzed failure, and, regarding to obtained results, common designing pavement structures procedures compared with the new way of AASHTO, and efficiency rate of related software investigated in two different climatic zone of Iran. Toward this process, Save- Hamadan and Qazvin- Boin Zahra cities selected as a case study and then studied. Results of software analyzing showed that the designs of old AASHTO method in tempered climate of country met all criteria of designing but in both of cold and warm areas, some failure at designed pavement structures via this method exceeded from allowed rate and according to presented failure, will be excessed more in future. This destruction in case project of cold area was longitude crack and was rutting of pavement structures subgrade in warm area. Then, probable causes of mentioned failures studied in pavement structures projects and procedures designed for rehabilitation pavement structures for met all of the designated criteria. Also, in Iran some suggestions indicated about required conductions for application of new method of AASHTO.
\end{abstract}

Keywords:Pavement Structures, AASHTO, Road Safety, Failure

\section{Introduction}

Regarding to significant climatic variation in Iran, which lead to various vectors across country expose different climate along their path, and also is with increasingly growth of vehicles that is toward meeting their needs to crossing facilities and providing more safety of those vehicles, the necessity of suitable designing and implanting pavement structure is sensed more.

Parameters of mixture design (type aggregates, bitumen type and effective percentage of bitumen,...) and climatic agents especially humidity, frosting and temperature changes effected directly and indirectly on pavement structure and lead to more costs for repairing roads[1,3]. In general, obtained mixed investigated features such as durability, resistance against spontaneous changes, and sensitiveness of mixed to humidity, so based on these features we select the best kind of mix.

\section{Author's Address}

${ }^{1}$ Department of Transportation, Germi Branch, Islamic Azad University, Germi, Iran

2 MS Graduate Transportation, Pasilo Consulting Engineering Company

${ }^{3}$ Department of Mechanical Engineering, Germi Branch, Islamic Azad University, Germi, Iran

E-mail: Mehdi.shahbazi72@yahoo.com, solvent is one of the most important factors,

In present common design method of pavement structure in country, based on AASHTO empirical 1993 method, effective agents on design such as weather condition and characteristics of subgrade aggregates were not considered well; e.g. for important material properties such as subgrade characteristics only we consider resistance of subgrade or for humidity condition the only involved material properties in thickness of layers, drainage coefficient $\mathrm{m}$ and assuming saturation state for subgrade is considered over the year, that this assumption leads to obtaining unsuitable thickness, especially considering dry climate of some area in Iran. In AASHTO method 2004 all of the effective material content in pavement structure contribute in design and this lead to more precise design of pavement structures. Code of Practice and its software has new capability for analyzing different kinds of pavement structures, but for utilization of this method in every part of world, it is necessary that models of function estimation and sensitiveness of predictive destructions investigated relative to different input parameters in local condition and models are calibrated 
again if necessary. New design method of AASHTO 2004 is more valid and cost effective, and in different design conditions from what has been experienced (e.g. in dense traffic) is more capable[4]. The main aim of Code of Practice, creating pavement structure design method proportional to present condition based on mechanistic-empirical principal. In 2005, National Research Council of Canada (NRCC) in comprehensive study, two kinds of main destruction including permanent alteration and fatigue crack covered from bottom to top and effect of using leveled data investigated in process of function estimation $[5,6]$. Their mainobjectiveis alteration of this method with present method of pavement structure (AASHTO 1993) in all states of country, method validity in relation to mechanic rules and assuring from accordance of results of software prediction of pavement structure function with recognized trends for studied aggregates (all were common used aggregates in Canada) [7]. The software calibration project was conducted by MnDOT in 2009 as one of the complete research in this scope. In this project, evaluation of the input data, identification of the software deficiency, analysis of sensitiveness and comparison of the results with expected level in common local conditions considering various structures for pavement (layers thickness and materials specifications) and the effect of the parameters change in the estimated failures were investigated [8]. MDSHA in 2007 investigated the appropriateness of method M-E PDG for Maryland State and sensitiveness of furnish and failure estimation models for main input parameters inputs for the state real pavement [9].

\section{Comparison of AASHTO 1993 with AASHTO 2004}

Mechanistic and experiential design method is more progressed in this regulation relative to current experiential methods (AASHTO) and it has caused to major changes in the models in terms of the method complexity. For using mechanistic principles in both structural models and weather models (temperature and humidity), more and complex pavement input data are required for implementing such models. These input data are distribution of axial load, materials complete specification, implementation factors, weather hourly data including temperature, precipitation, sun shine, cloud coverage and relative humidity etc. On the other hand, according to importance level of the project and current information, three input levels can be considered. Thus, much more effort is required for evaluation and institutionalization of this method in road construction firms [10].There was a unit performance criterion in AASHTO called PSI, while, in new methods different criteria such as crack disruption, cracking, roughness, identify pavement condition.

In AASHTO 1993, furnish diameter was calculated directly, while in AASHTO 2004 trial and error method is used. New flexible and modified pavement mechanistic- experiential design requires design engineers in trial and error and repetitive operation. The designer should choose a test primary design and then analyze the design in detail in software to identify the conformity of the defined design criteria. Flexible furnish performance criteria considered in this regulation include: permanent deformation (crack disruption) fatigue cracks (from up to bottom and bottom to up), thermal cracks and international roughness index (IRI). If the proposed design does not meet the performance criteria, the design is modified and reanalyzed until meet the criteria.

AASHTO 1993 has been expanded according to the information obtained from Etowah site in Illinois State in America, which for considering environmental conditions only seasonal adjusted module of the substrate soil and the layers drain coefficients, while AASHTO 2004 considers a set of weather information such as temperature, precipitation, wind velocity, relative humidity.

In AASHTO 1993 other concept of ESAL was used for defining traffic three levels, while in AASHTO 2004 the concept of load spectrum is used [11, 12]. According to what mentioned, AASHTO 2004 shaped based on numerical methods has fundamental differences with AASHTO 1993 which some of them are pointed.

Table 1. Fundamental differences between AASHTO 1993 and AASHTO 2004

\begin{tabular}{|l|l|l|}
\hline Characteristics & $\begin{array}{l}\text { AASHTO } \\
1993\end{array}$ & $\begin{array}{l}\text { AASHTO } \\
2004\end{array}$ \\
\hline $\begin{array}{l}\text { Performance } \\
\text { criterion }\end{array}$ & PSI & $\begin{array}{l}\text { Separation of } \\
\text { failures and } \\
\text { isolated } \\
\text { investigation }\end{array}$ \\
\hline $\begin{array}{l}\text { Calculation of } \\
\text { the proper } \\
\text { thickness }\end{array}$ & $\begin{array}{l}\text { Direct } \\
\text { calculation } \\
\text { of the layer } \\
\text { thickness }\end{array}$ & $\begin{array}{l}\text { Trial and error } \\
\text { method }\end{array}$ \\
\hline $\begin{array}{l}\text { Layers input } \\
\text { parameters }\end{array}$ & Very limited & $\begin{array}{l}\text { Vary } \\
\text { expanded and }\end{array}$ \\
\hline
\end{tabular}




\begin{tabular}{|l|l|l|}
\hline & & $\begin{array}{l}\text { capability of } \\
\text { proposing in } \\
\text { three input } \\
\text { levels } \\
\text { dependent on } \\
\text { importance }\end{array}$ \\
\hline $\begin{array}{l}\text { Conformation } \\
\text { with the project } \\
\text { place } \\
\text { characteristics }\end{array}$ & $\begin{array}{l}\text { Conformity } \\
\text { with Etowah } \\
\text { site in } \\
\text { America } \\
\text { Illinois state }\end{array}$ & $\begin{array}{l}\text { According to } \\
\text { project site } \\
\text { weather } \\
\text { information }\end{array}$ \\
\hline
\end{tabular}

\section{Collected data for modeling of the selected} items in software

For doing case study,two plots were chosen in two cold region and hot regions. These plots are located in Saveh-Hamadan highway and second band of Qazvin-Boein Zahra highway.

For obtaining data on each project, the documents were obtained including traffic studies handbooks, the band first and second steps studies, reports on the experiments of soil mechanic and the route geo-technique, metrology information and statistics, and the handbooks of asphalt layers mixture design sheets and in case of lack of documents the levels 2 and 3 were used. Also, it is necessary to modify some data before entering the data to software. Change in the value sections and modification of the manner of separation of vehicles are such changes. The data have been obtained using relations in other data (input $2^{\text {nd }}$ level). For obtaining performance parameters values by their reliability coefficients the values in AASHTO 2004 regulation were used.

Among the studied projects, Saveh-Hamadan highway has complete information due to the importance of the highway and conducting the studies by consulting firms as teamwork. For this reason, less assumptive values were used for the data of this highway.

\section{Analysis of the software results}

The software used in the first step predicts failures according to mean values of inputs; these predicted values for failure were mean and they can be considered as estimation for safety level of $50 \%$ it means that there is $50 \%$ probability that real failure is more than estimated mean. In the software output graphs one of them is always mean graph.

Practically, in the projects it cannot be consideredsafety factor of $50 \%$ and the safety factors are selected higher than 50\% according to the road importance. In the case projects of this research, according to type of the highways, the chosen safety factorsfor all failure types and roughness are higher than $90 \%$. Predicted failure software calculates safety factorand displays its curve in the output graphs.

According to the above mentioned, the failure curve in the related safety factoris the criterion for acceptance of furnish performance and the mentioned graph should not be higher than considered limit for that specific failure.

\subsection{Analysis of the results of Saveh-Hamadan highway software analysis}

The results of analysis of Saveh-Hamadan highwayshow that in the life of this project, no crack happens. In the figures 1-4, the results of alligator crack, longitudinal cracks, track disruption amount and international roughness index (IRI) of furnish of this road have been investigated.

According to the graph 1, at the beginning of operation of this road, the furnish alligator skin crack mean was zero but by passing of time a little crack will be seen in pavement which this amount will be $2 \%$ of total pavement surface at the end of the project.

This software calculated alligator crack $2 \%$ at the beginning of the peroration by applying safety factorin total pavement surface which the mean will be increased by approximately similar trend with alligator crack and at the end of the period, it will be less than $4 \%$ of the pavement total surface. Also, the amount of alligator crack was considered less than allowable limit thus, pavement does not meet the criterion of fatigue crack from bottom to up. According to the figure 2 it is seen that the longitudinal crack of the pavement mean is zero at the beginning of operation which increase by passing of time. Also, longitudinal crack of pavement in the project whether in the surface or in the depth will not exceed than allowable limit.

In this software the surface longitudinal crack was considered about $300 \mathrm{f} / \mathrm{m}$ by safety level at the beginning of pavement operation that increases by passing of time and 81 months after beginning of operation it will not exceed than allowable limit. Thus, it does not meet the fatigue crack from bottom to up criterion. 


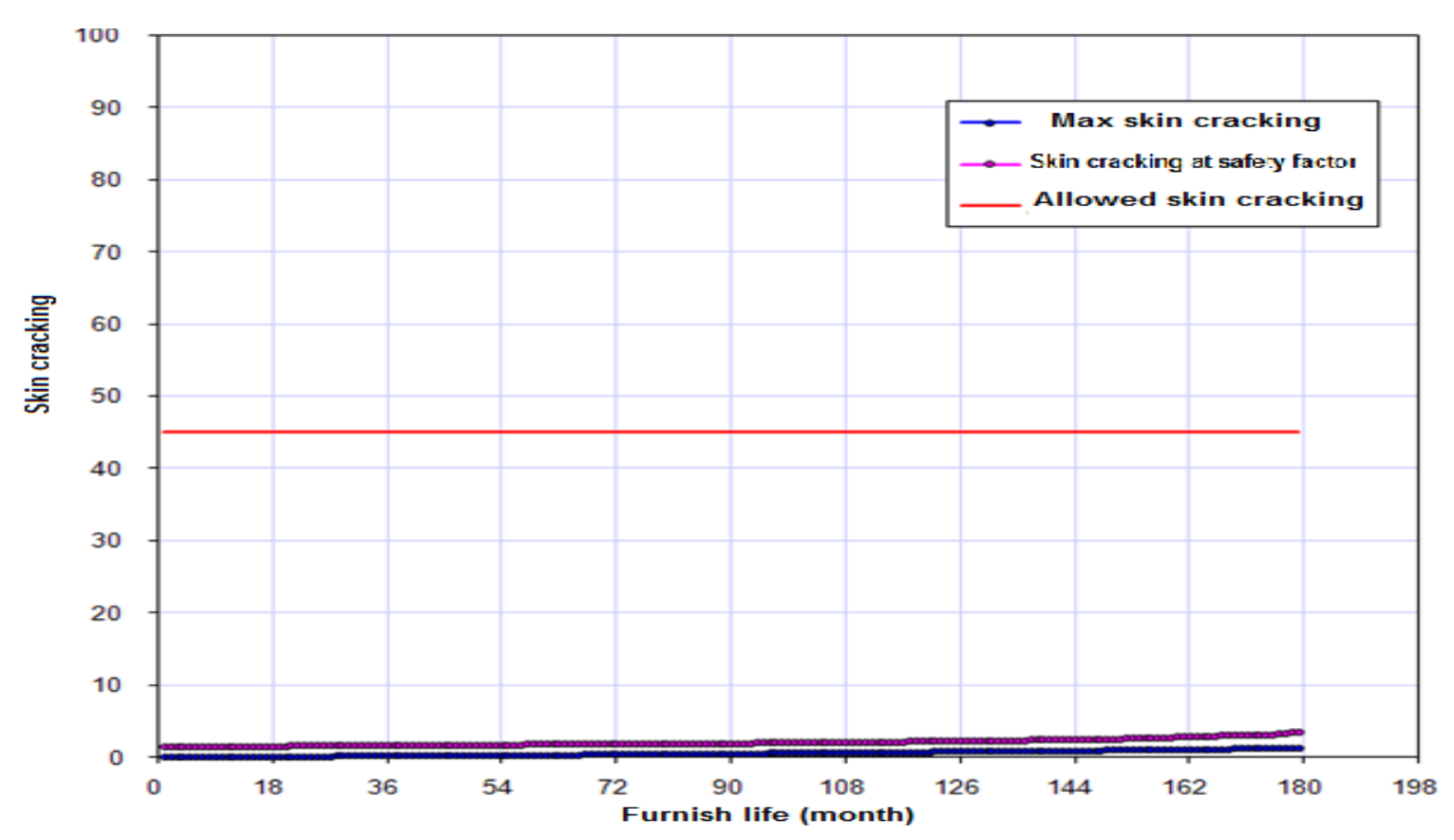

Fig. 1: alligator cracks of Saveh-Hamadan highway in time

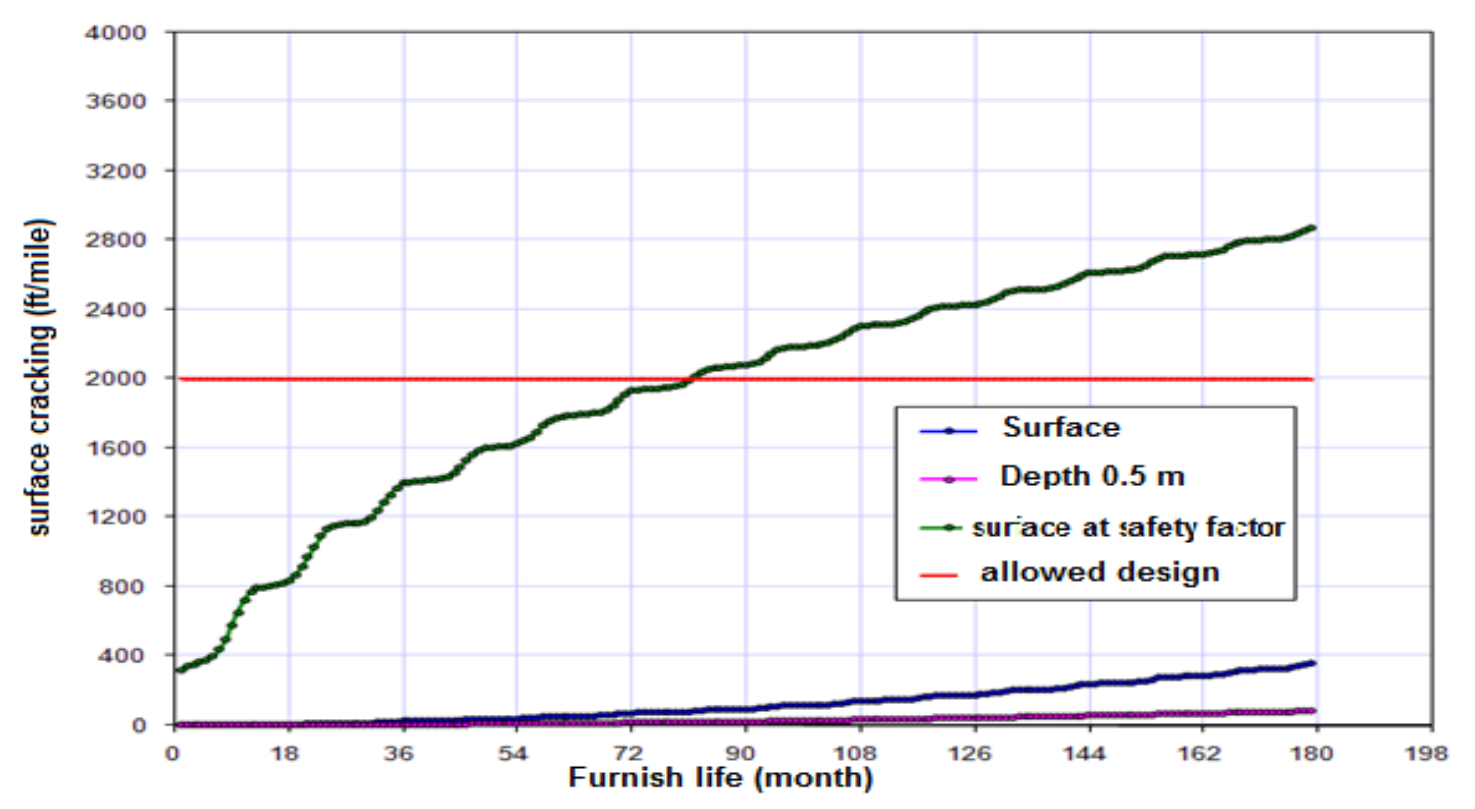

Fig. 2: Longitudinal crack in the Saveh-Hamadan highway in time

The figure 3 depicts the pavement track dispersion in different pavement layers. According to the graph, at the beginning of pavement operation, track dispersion will be seen under each layer of pavement that it is insignificant for asphalt layer. By passing of time the depth of track dispersion will be increased under all furnish layers. The track dispersion graph is conformed to each other under the foundation and sub-base layers and it means that track dispersion of these layers will not be the same. Asphalt track dispersion will be increased until the end of the project period but in the under foundation and base layers after passing of operation time, the track dispersion amount will not be exceeded than allowable limit whether under the layer or under the total pavement and as a result pavement is acceptable in terms of track dispersion. 


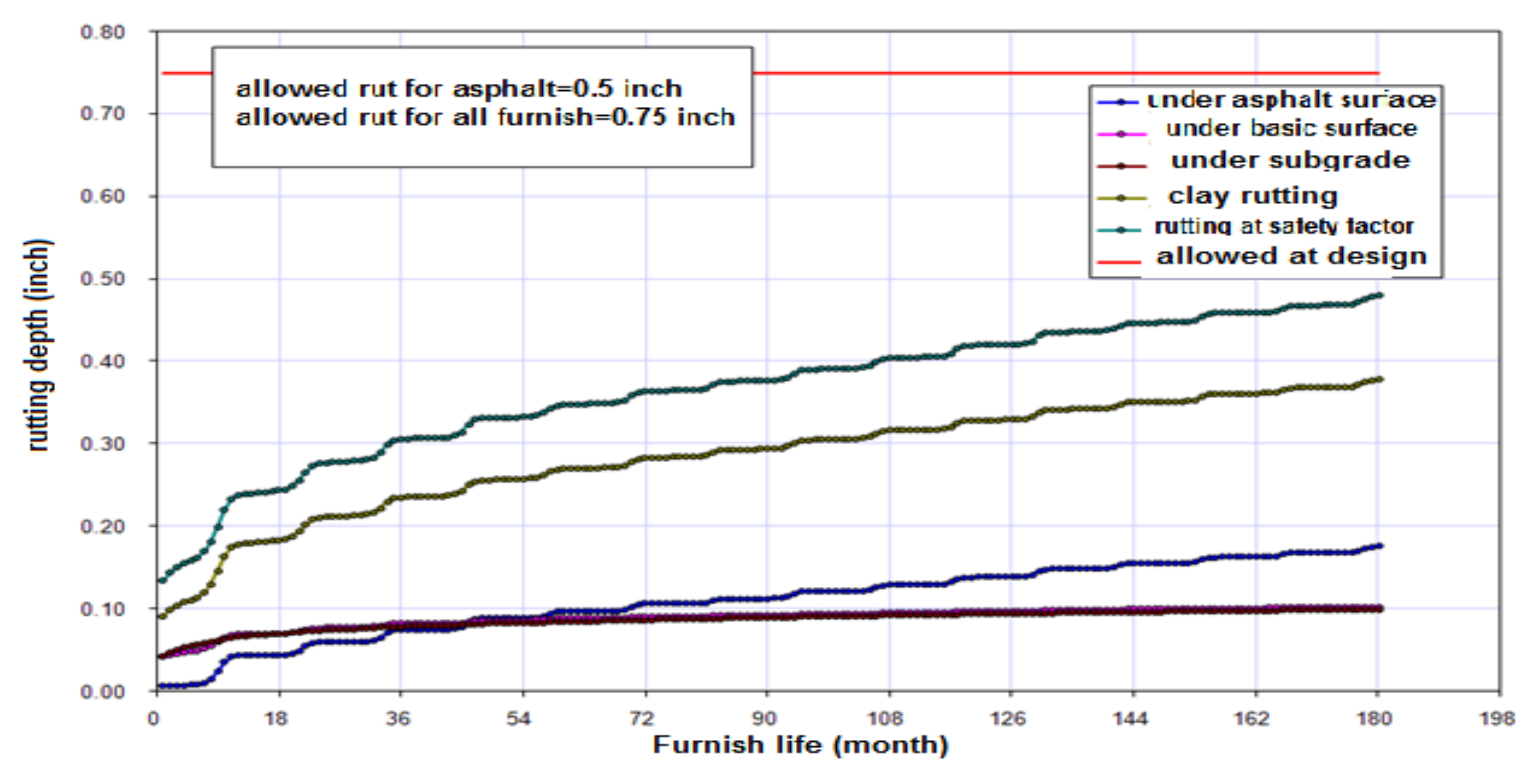

Fig. 3:Saveh-Hamadan highway pavement layers track dispersion in time

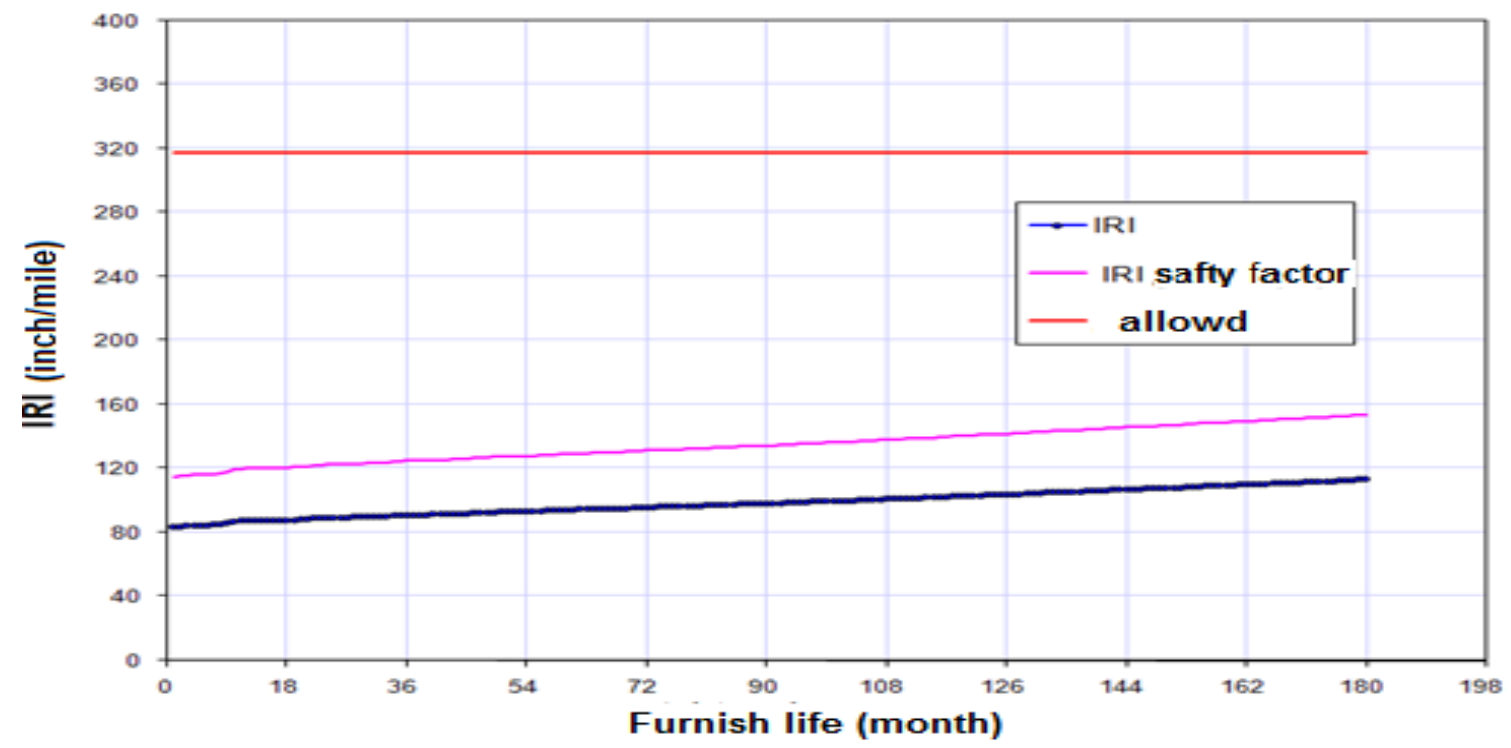

Fig. 4: Saveh-Hamadan highway pavement layer IRI in time

Table 2: summary of Saveh-Hamadan highway pavement performance result

\begin{tabular}{|l|l|l|l|l|l|}
\hline $\begin{array}{l}\text { Performance } \\
\text { criterion }\end{array}$ & $\begin{array}{l}\text { Final } \\
\text { failure }\end{array}$ & $\begin{array}{l}\text { Final } \\
\text { safetyfactor }\end{array}$ & $\begin{array}{l}\text { Predicted } \\
\text { failure }\end{array}$ & $\begin{array}{l}\text { Predicted } \\
\text { safetyfactor }\end{array}$ & Status \\
\hline Final IRI(inch/m) & 317.4 & 90 & 113.3 & 99.999 & Acceptable \\
\hline $\begin{array}{l}\text { Asphalt } \\
\text { longitudinal } \\
\text { crack(f/m) }\end{array}$ & 2000 & 90 & 364 & 79.71 & Unacceptable \\
\hline $\begin{array}{l}\text { Alligator } \\
\text { crack(f/m) }\end{array}$ & 45 & 90 & 1.2 & 99.999 & Acceptable \\
\hline $\begin{array}{l}\text { Latitudinal } \\
\text { crack(f/m) }\end{array}$ & 1000 & 90 & 1 & 99.999 & Acceptable \\
\hline $\begin{array}{l}\text { Asphalt track } \\
\text { dispersion(inch) }\end{array}$ & 0.5 & 90 & 0.18 & 99.999 & Acceptable \\
\hline $\begin{array}{l}\text { Total furnish track } \\
\text { dispersion }\end{array}$ & 0.75 & 90 & 0.38 & 99.999 & Acceptable \\
\hline
\end{tabular}


According to the figure 4, pavement roughness will be increased approximately in constant trend but even at the end of the project, the long distance considered for designed pavement will meet the roughness criterion.

As table 2 and figure 2 depict pavement in this road does not meet the longitudinal cracking criterion. The defined criterion is longitudinal cracking $2000 \mathrm{f} / \mathrm{m}$ by safety factorof $90 \%$ at the end of operation period; it means that it is expected that at the end of the period, furnish by safety factor $90 \%$ has no cracking more than 2000 $\mathrm{f} / \mathrm{m}$. According to graph, the time of going beyond pavement limit for longitudinal crack with the mentioned safety factoris 81 months after beginning of operation.

\subsection{Analysis of the results of Qazvin-Boein Zahra highway software}

The results of pavement analysis of QazvinBoein Zahra highway show that in the life of this project, no crack happens. Also, in the figures 5-8, the results of alligator crack, longitudinal cracks, track disruption amount and IRI of pavement of this road have been investigated.

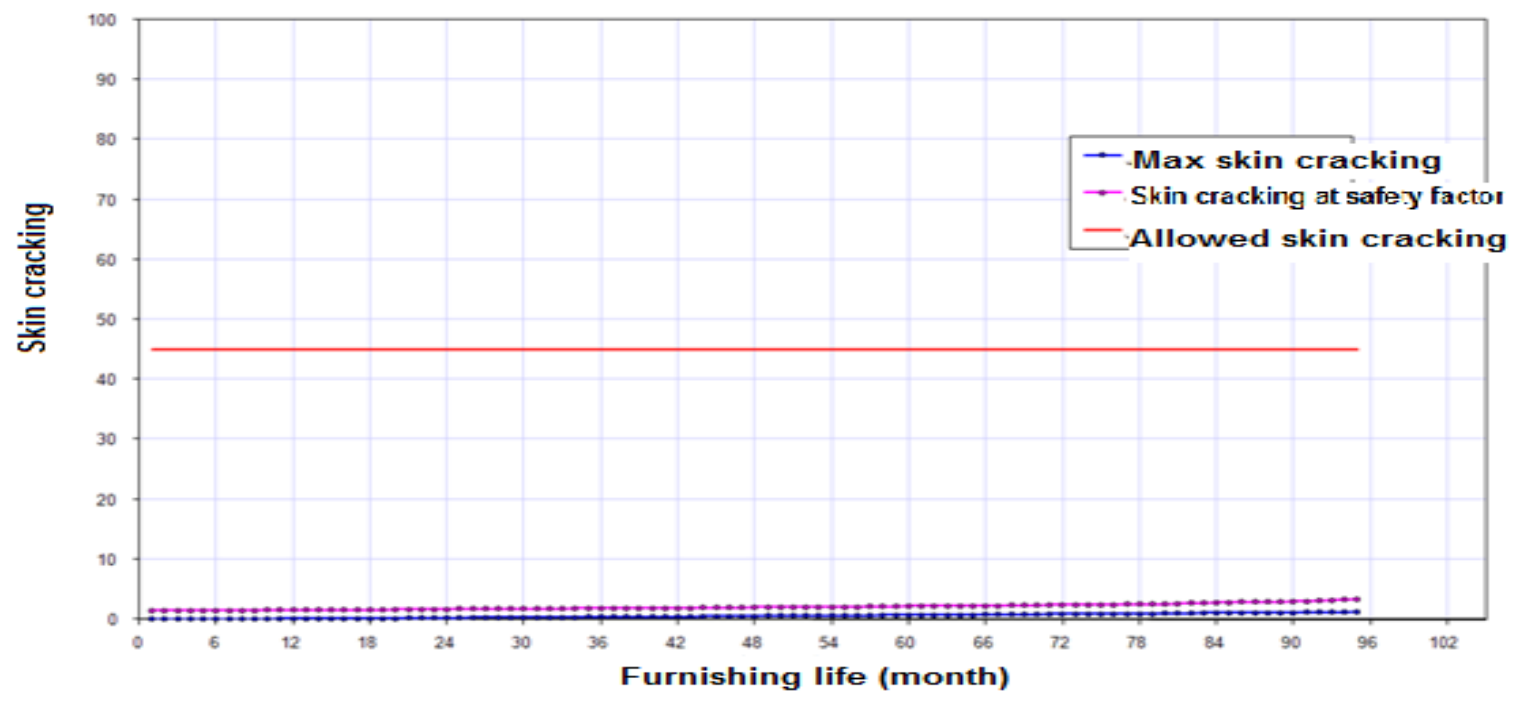

Fig. 5: Alligator cracks of Qazvin-Boein Zahra highway in time

According to the figure 5, at the beginning of operation of this road, the alligator skin crack mean was zero but by passing of time a little crack will be seen in pavement which this amount will be $2 \%$ of total pavement surface at the end of the project.The mentioned software calculated alligator crack $2 \%$ at the beginning of the operation by applying safety factor in total pavement surface which the mean will be increased by approximately similar trend with alligator crack and at the end of the period, it will be less than $4 \%$ of the total pavement surface. Also, the amount of alligator crack was considered less than allowable limit thus, pavement meets the criterion of fatigue crack from bottom to up.According to the figure 6 it is seen that at the beginning of the road operation, the longitudinal crack of the pavement mean is zero which does not increase by passing of time; so that, at the end of the furnish project period also longitudinal crack of pavement whether in the surface or in the depth of half meter will be
trivial.In this software the surface longitudinal crack was considered about $300 \mathrm{f} / \mathrm{m}$ that increases by passing of time and never goes beyond allowable level. Thus, it meets the furnish fatigue crack criterion from bottom to up. The figure 7 shows that at the beginning of pavement operation the pavement track dispersion will be seen in the pavement layers. Track dispersion of the asphalt layer will be increased until the end of the project period but in the under subbase and base layers after passing of time the depth of track dispersion will be decreased and finally it becomes trivial. The track dispersion in the under foundation and subgrid layers is more than under foundation layer. Basically, track dispersion is similar under the under subbase and base layers but the increase rate of dispersion depth is reduced early in the under base layer than subbase layer. The graph shows that in the pavement life the track dispersion of each layer will not increase than allowable level. As a result pavement is acceptable in terms of track dispersion. 


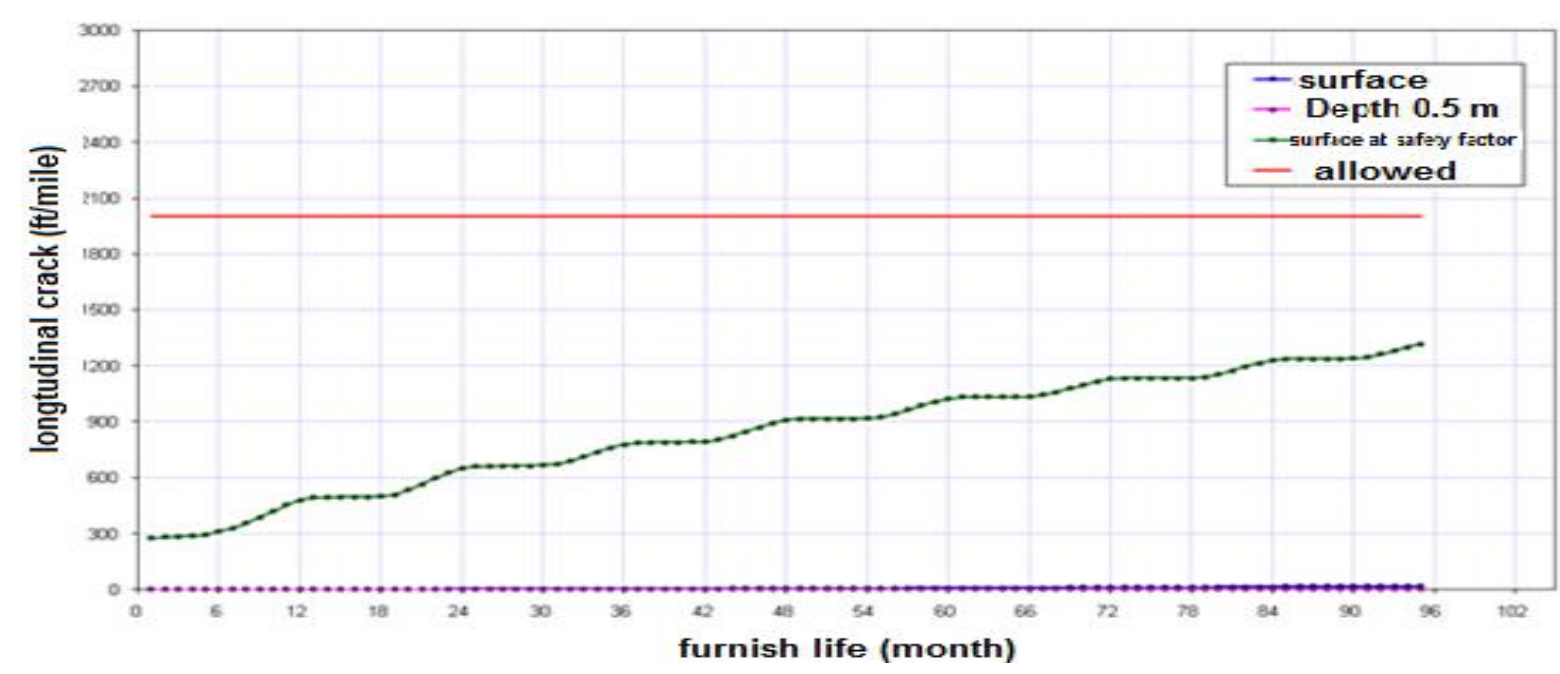

Fig. 6. Longitudinal crack in the Qazvin-Boein Zahra highway in time

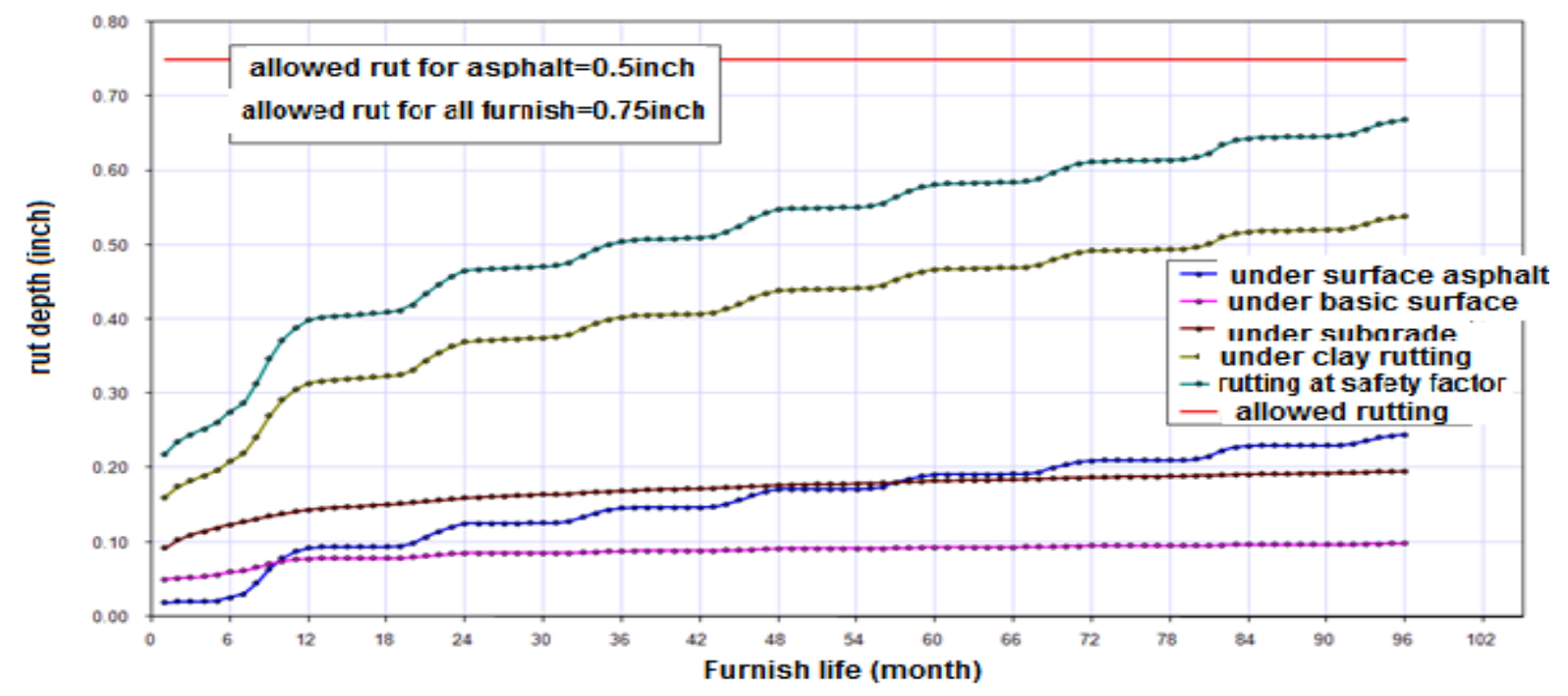

Fig. 7: Qazvin-Boein Zahra highway pavement layers track dispersion in time

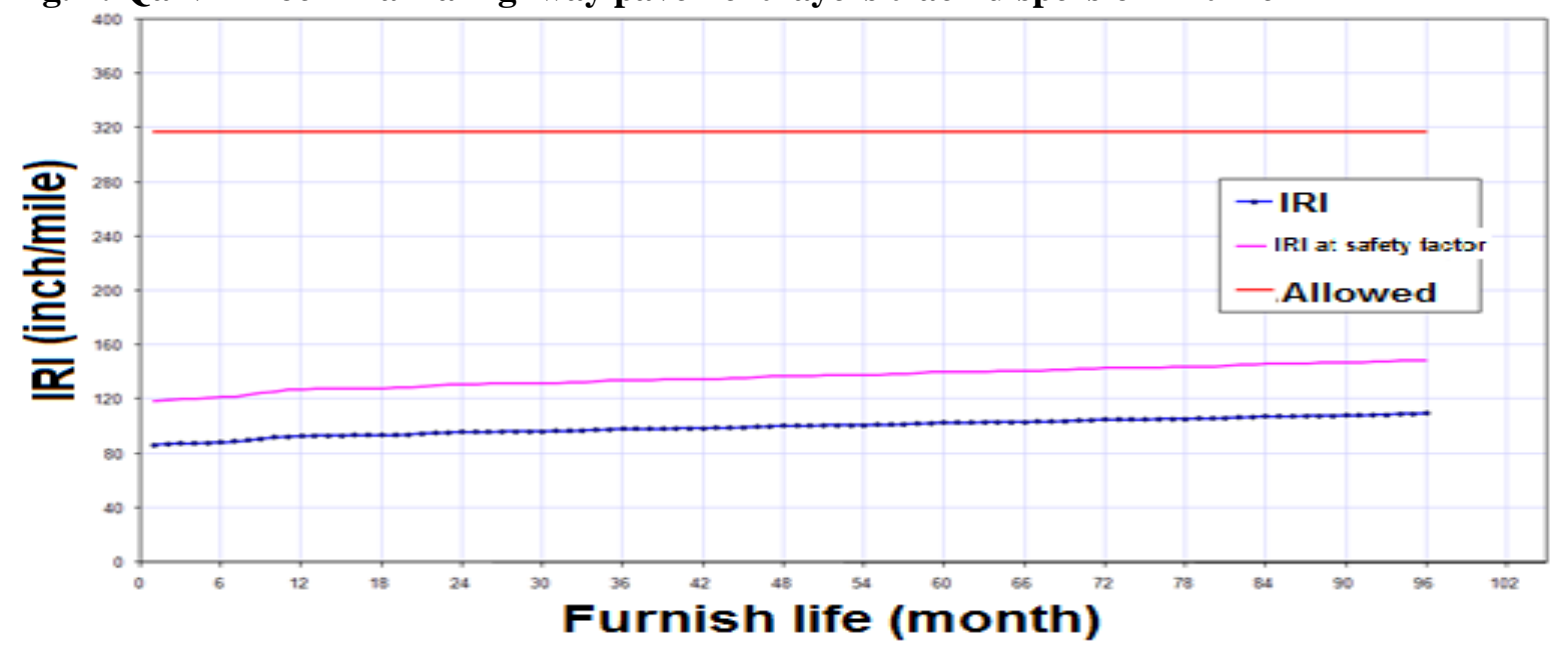

Fig. 8: Qazvin-Boein Zahra highway pavement layer IRI in time 
According to the figure 8 , pavement roughness will be increased approximately in constant trend but even at the end of the project, the long distance considered for designed pavement will meet the roughness criterion.

Table 3: summary of Qazvin-Boein Zahra highway pavement performance result

\begin{tabular}{|l|l|l|l|l|l|}
\hline $\begin{array}{l}\text { Performance } \\
\text { criterion }\end{array}$ & $\begin{array}{l}\text { Final } \\
\text { failure }\end{array}$ & $\begin{array}{l}\text { Final } \\
\text { safetyfactor }\end{array}$ & $\begin{array}{l}\text { Predicted } \\
\text { failure }\end{array}$ & $\begin{array}{l}\text { Predicted } \\
\text { safetyfactor }\end{array}$ & Status \\
\hline Final IRI(inch/m) & 317.4 & 90 & 118.5 & 99.999 & Acceptable \\
\hline $\begin{array}{l}\text { Asphalt } \\
\text { longitudinal } \\
\text { crack(f/m) }\end{array}$ & 2000 & 90 & 35.8 & 94.87 & Acceptable \\
\hline $\begin{array}{l}\text { Alligator } \\
\text { crack(f/m) }\end{array}$ & 45 & 90 & 1.9 & 99.999 & Acceptable \\
\hline $\begin{array}{l}\text { Latitudinal } \\
\text { crack(f/m) }\end{array}$ & 1000 & 90 & 1 & 99.999 & Acceptable \\
\hline $\begin{array}{l}\text { Asphalt track } \\
\text { dispersion(inch) }\end{array}$ & 0.5 & 90 & 0.29 & 99.05 & Acceptable \\
\hline $\begin{array}{l}\text { Total pavement } \\
\text { track dispersion }\end{array}$ & 0.75 & 90 & 0.6 & 91.48 & Acceptable \\
\hline
\end{tabular}

As table 3 shows pavement considered for this highway meet all criteria and it is best choice for this road.

4.3Types of early failure and occurrence reasons The asphalt failure might be as a result of heavy traffic, resultant from humidity and atmosphere unpleasant conditions, as a result of improper mixture of asphalt or asphalt inappropriate implementation, weak infrastructure in the road construction or result of other factors. Table 4 summarizes failures in these five groups.

Table 4: types of failure and their reasons

\begin{tabular}{|l|l|l|}
\hline Serial & Failure group & Failures placed in this group \\
\hline 1 & Failures as a result of traffic & $\begin{array}{l}\text { Mosaic crack- edge crack- sigmoid track, hollow track } \\
\text { groove, recesses, wave, extroversion and introversion }\end{array}$ \\
\hline 2 & Failures as a result of weather & $\begin{array}{l}\text { Settlement of the road sides, block crack, longitudinal } \\
\text { track, latitudinal crack, edge track, protuberance, } \\
\text { hollow, introversion and extroversion }\end{array}$ \\
\hline 3 & $\begin{array}{l}\text { Failures as a result of asphalt } \\
\text { bitumenring, wave, introversion and extroversion }\end{array}$ \\
\hline 4 & $\begin{array}{l}\text { Failures as a result of weak } \\
\text { infrastructure }\end{array}$ & Groove, pit, protuberance, edge track \\
\hline 5 & $\begin{array}{l}\text { Failures as a result of other } \\
\text { factors }\end{array}$ & Patching, fatigue, railway passage, granular polishing \\
\hline
\end{tabular}

4.4Analysis of the causes of roads failure and modification methods for reducing failures

Since among pavement main failure types, only two failures including longitudinal crack and track dispersion is significant and beyond the allowable limit in the studied routes, in this section the causes of occurrence of these failures and the proposed modification methods for reduction of these failures are investigated.

a) Causes of occurrence of fatigue crack from up to bottom or longitudinal cracks

There are different theories for mechanism causingfatigue crack from up to bottom or longitudinal cracks but there is no final information for proving superiority of a theory 
on others. Some possible theories can be as follows (1):

-extensional stresses and strains resultant from wheel load and occurred stresses in the surface -mixed crossing in the hot asphalt surface happened due to the effect of radial tires with high contact pressure near the tire edge.

-sever fatigues of the surface hot asphalt mixture and the effect of thickness

-the substrate resistance

-percentage of the void spaces of asphalt

-effective bitumen amount

-changing of asphalt layer thickness and changing the mixing project parameters from possible methods for modification of designing is done for reduction of longitudinal track.

b) The causes of occurrence of permanent deformation or track dispersion failure

The present definition of surface failure track dispersion is a failure happened in the route of wheels due to inflexible and irrevocable deformations of one or all layers of pavement and subgrade. These irrevocable deformations are usually as the results of following factors [1]. Density of the asphalt layers due to unilateral loads pressure and furnish strengthening during operation period which indeed, continuation of the primary densities by rollers and tracks that caused uninformed in the width of the furnish surface.

Lateral movements or elastic replacement (irrevocable) of the materials (hot asphalt, granular base and subgrade soils) due to the effect of wheels. Most of the sever failures of track dispersion and deformation are results of lateral replacement or shear resistance of a pavement layers and they are not result of onedimensional density.

Many factors impact on the permanent deformation of the pavement layers. Some of these factors can be controlled or modified; while others are external factors and they cannot be controlled. However, some factors including the layer thickness remains fixed in the project period, others change as seasonal, monthly, hourly or with life of pavement. The following factors influence permanent deformations of the different layers of pavement structure:

- Thickness and dynamic module of the hot asphalt layer

-Bitumen grade in hot asphalt mixture

-void space percentage in asphalt layers

-effective bitumen percentage in asphalt layers

-type, thickness and hardness of the base -traffic load, contact surface and tire pressure -project traffic velocity

-traffic dispersion (distribution)

-temperature and environmental conditions

\subsection{Possible methods for modification of design} for reducing track dispersion failure

When estimated track dispersion is beyond design necessities test design should be modified so that lead to increase of structural power and improve the quality of material in all layers. Different design parameters have various effects on different performance size. The first issue that should be considered completely is evaluation of the critical values of estimated primary track dispersion depth for layers materials types in the project. This step is an important step since project selection and its amendment should be proportionate with a layer or layers which have the highest depth of estimated track dispersion. In other words, attention to materials layer that high percentage of track dispersion total depth is prior. For reduction of track dispersion in any layer a specific method is used.

\subsection{The roads pavement project modification}

In Saveh-Hamadan highway, according to this fact that failure in this road is not longitudinal track, it cannot change the subbase resistance characteristics since if it is necessary to apply changes, it should be done in order to reduce subbase resistance that it is not rational. On the other hand, if we want to increase asphalt layers thickness, according to the mentioned cases explained in the previous section, we should increase bitumen hardness concurrently; for instance, if we consider the sum of asphalt layers thickness 7 inch instead of 6 inch and bitumen type 60-70 instead of bitumen 85-100 due to coldness of the region it will cause to thermal tracks in the asphalt layer. By software analysis it was specified that when the asphalt layer is fixed and change the asphalt type and use the fresh hardened bitumen (bitumen 60-70 instead of 85100), then the problem of thermal track in pavement will be remained.

According to the above mentioned, the only way that can be proposed for reduction of the route longitudinal crack is revaluation of low void space percentage characteristics (Va) and effective bitumen value in the route asphalt mixture; however, this plan should be implemented so that pavement layer failures like permanent deformation and thermal cracks. The required conditions for these changes are reexamination and studies of the route mixture 
project. Using current Marshall curves in the Saveh-Hamadan route mixture project sheets handbook, the percentage of the void spaces in the asphalt layers(from $4 \%$ to $2.9 \%$ ) and the bitumen is obtained by this void space percentage from related curves and enter in the software, the output of software showed the failures have been removed by these changes. Thus, we conclude that by reduction of void space percentage and increase the effective bitumen it can be removed the failure resultant from longitudinal cracks. It should be pointed that in void space percentage $2.9 \%$, the Marshall strength is increased.

\subsection{Conclusion of the research case studies}

1-Conclusion of the Saveh-Hamadan project

According to the results of the software it is seen that in the Saveh-Hamadanthe layers is similar in both old method of AASHTO 1993 and Mechanistic and experiential method. Although in the mentioned pavement the longitudinal cracks have been considered more than allowable limit, but as in the pavement modification section was mentioned, this problem cannot be solved by changing the layers thickness; but the failure is resulted from asphalt layer mixture project parameters and the only way to eliminate the road failure is also modification of the void space percentage and effective bitumen parameters. The necessary conditions for chaining these parameters are reexamination and studies of the mixture project.

Table 5: Saveh-Hamadan pavement layers thickness by AASHTO 1993 method

\begin{tabular}{|c|c|c|c|c|c|c|}
\hline \multirow{2}{*}{$\begin{array}{l}\text { Under } \\
\text { founda } \\
\text { tion } \\
\text { thickne } \\
\text { ss }\end{array}$} & \multirow{2}{*}{$\begin{array}{l}\text { founda } \\
\text { tion } \\
\text { thickne } \\
\text { ss }\end{array}$} & \multicolumn{3}{|c|}{$\begin{array}{ll}\text { Asphalt } & \text { layers } \\
\text { thickness } & \end{array}$} & \multirow[t]{2}{*}{$\begin{array}{l}\mathrm{CB} \\
\mathrm{R}\end{array}$} & \multirow[t]{2}{*}{$\begin{array}{l}\mathrm{S} \\
\mathrm{N}\end{array}$} \\
\hline & & $\begin{array}{l}\text { Firs } \\
\mathrm{t} \\
\text { bin } \\
\text { der }\end{array}$ & $\begin{array}{l}\text { Seco } \\
\text { nd } \\
\text { bind } \\
\text { er }\end{array}$ & $\begin{array}{l}\text { Top } \\
\text { eka }\end{array}$ & & \\
\hline $30 \mathrm{~cm}$ & $15 \mathrm{~cm}$ & $\begin{array}{l}6 \\
\mathrm{~cm}\end{array}$ & $5 \mathrm{~cm}$ & $4 \mathrm{~cm}$ & 15 & $\begin{array}{l}4 . \\
8\end{array}$ \\
\hline \multicolumn{7}{|c|}{$\begin{array}{l}\text { Table 6: Saveh-Hamadan pavement } \\
\text { thickness by AASHTO } 2004 \text { method }\end{array}$} \\
\hline \multirow{2}{*}{$\begin{array}{l}\text { Under } \\
\text { founda } \\
\text { tion } \\
\text { thickn } \\
\text { ess }\end{array}$} & \multirow{2}{*}{$\begin{array}{l}\text { founda } \\
\text { tion } \\
\text { thickn } \\
\text { ess }\end{array}$} & \multicolumn{3}{|c|}{$\begin{array}{l}\text { Asphalt layers } \\
\text { thickness }\end{array}$} & \multirow[t]{2}{*}{$\begin{array}{l}\mathrm{M} \\
\mathrm{r}\end{array}$} & \multirow[t]{2}{*}{$\begin{array}{l}\text { Peri } \\
\text { od }\end{array}$} \\
\hline & & $\begin{array}{l}\text { Firs } \\
\mathrm{t} \\
\text { bin } \\
\text { der }\end{array}$ & $\begin{array}{l}\text { Sec } \\
\text { ond } \\
\text { bind } \\
\text { er }\end{array}$ & $\begin{array}{l}\text { Top } \\
\text { eka }\end{array}$ & & \\
\hline $30 \mathrm{~cm}$ & $15 \mathrm{~cm}$ & $\begin{array}{l}6 \\
\mathrm{~cm}\end{array}$ & $\begin{array}{l}5 \\
\mathrm{~cm}\end{array}$ & $\begin{array}{l}4 \\
\mathrm{~cm}\end{array}$ & $\begin{array}{l}8 \\
0 \\
5\end{array}$ & $\begin{array}{l}15 \\
\text { yea } \\
\text { rs }\end{array}$ \\
\hline
\end{tabular}

2-Conclusion of the Qazvin-Boein Zahra project According to the results of the software, it is seen that in the Qazvin-Boein Zahra road, which in this project is located in temperament region, the obtained thickness for the layers is similar in both old method of AASHTO and Mechanistic and experiential method. By implementing pavement with obtained thickness in the AASHTO method all performance criteria considered for furnish include all key failures and IRI. The obtained results are expected since the relations used in Mechanistic and experiential method for estimation of the failures and other pavement performance parameters are experiential relations obtained by analysis of the pavement test in different regions in America, they are relations for data mean. Hence, it is not surprising that these relations offer the most accurate results for temperament weather conditions.

Table 7: Qazvin-Boein Zahra pavement layers thickness by AASHTO 1993 method

\begin{tabular}{|l|l|l|l|l|}
\hline $\begin{array}{l}\text { subbase } \\
\text { thicknes }\end{array} \mathrm{s}$ & $\begin{array}{l}\text { base } \\
\text { thickness }\end{array}$ & \multicolumn{2}{|l|}{$\begin{array}{l}\text { Asphalt layers } \\
\text { thickness }\end{array}$} & period \\
\cline { 3 - 4 } & & $\begin{array}{l}\text { First } \\
\text { binder } \\
\text { and } \\
\text { Second } \\
\text { binder }\end{array}$ & Topeka & \\
& & $\begin{array}{l}6 \\
+6 \mathrm{~cm}\end{array}$ & $4 \mathrm{~cm}$ & $\begin{array}{l}12 \\
\text { years }\end{array}$ \\
\hline $15 \mathrm{~cm}$ & $15 \mathrm{~cm}$ & & \\
\hline
\end{tabular}

Table 8: Qazvin-Boein Zahra furnish layers thickness by AASHTO 2004 method

\begin{tabular}{|c|c|c|c|c|c|}
\hline \multirow{2}{*}{$\begin{array}{l}\text { subbase } \\
\text { thickne } \\
\text { ss }\end{array}$} & \multirow{2}{*}{$\begin{array}{l}\text { base } \\
\text { thickne } \\
\text { ss }\end{array}$} & \multicolumn{2}{|c|}{$\begin{array}{l}\text { Asphalt layers } \\
\text { thickness }\end{array}$} & \multirow[t]{2}{*}{$\mathrm{Mr}$} & \multirow[t]{2}{*}{$\begin{array}{l}\text { Perio } \\
\text { d }\end{array}$} \\
\hline & & $\begin{array}{l}\text { First } \\
\text { binde } \\
r \text { and } \\
\text { Secon } \\
d \\
\text { binde } \\
r\end{array}$ & $\begin{array}{l}\text { Topek } \\
\text { a }\end{array}$ & & \\
\hline $17 \mathrm{~cm}$ & $15 \mathrm{~cm}$ & $\begin{array}{l}6+6 \\
\mathrm{~cm}\end{array}$ & $4 \mathrm{~cm}$ & $\begin{array}{l}94 \\
5\end{array}$ & $\begin{array}{l}12 \\
\text { years }\end{array}$ \\
\hline
\end{tabular}

\section{Conclusion}

In spite of being experimental nature of the software MEPDG, its exact modeling is the biggest advantages; however, this method is complex since it requires more and highly accurate data. For using this software in Iran, particularly level 1 and level 2, unfortunately 
there is no weather and traffic data which are most important factors in pavement performance. Also, this software needs super mixture project method data for accurate analysis of the asphalt layers that it necessities the replacement of the superpave method instead of Marshall Method.

2) By investigation and comparison of the granular materials in Iran (continuous granulation for hot asphalt according to journal 101) and superpave method it was identified that there are differences in specifications of these granulations, so it is necessary to investigate possibility of production and control of the granular with superpave granulation in Iran.

3) By using MEPDG software it was observed that the produced mixtures by Marshal Method do not show good performance against failures including permanent deformation and fatigue cracks and track dispersion.

4) Since mixtures with high resistance against track dispersion are mostly hard, due to friction they become dense, it is necessary to provide condition to good density by correct selection of the layer thickness, density equipments and rolling methods. It should be pointed that during this process other bitumen materials properties including resistance against fatigue and durability should be preserved.

5) According to the role of related layer in the road construction durability and stability are main parameters. Obtaining mixture that meets the materials needs and properties for durability and stability is necessary. As we know, stability is related to mixture, while durability depends on mixture method and thickness. Using superpave mixture method and simulation in software MEPDG provide gaining the main goal.

6) From investigation on the asphalt mixture mechanical properties it is concluded that two main parameters of resistance against instable track dispersion (problems related to asphalt mixture) and against fatigues (problems related to asphalt mixture and thickness design) depend on two factors: first, bitumen adhesive thermal sensitivity that directly effects on the mixture thermal sensitivity and the other is level of filling the rocky materials void spaces by bitumen.

7) The designing common methods do not show the bitumen mixture behavior in the future, therefore it is necessary to investigate dense mixture volume specification in addition to mechanical properties. For this reason, studies on mixtures design, manner and severity of the samples density are important parameters.

8) In the new methods of mixture in addition to considering the mixture stability, durability is also considered.

9) The common design methods do not consider all factors on mechanical performance of the new asphalt mixtures, so they are not appropriate for nowadays traffic.

\section{References}

[1] Ali M., Mokhtar M., Chiesa M., Armstrong P., Cooling change-point model of communityaggregate electrical load, Energy and Buildings, 43 (2011).

[2] Everson J., Kopala E., Lazofson L.,Choe H., Pomerleau D., "Sensor performance and weather effects modeling for intelligent transportation systems (ITS) applications", Proc. SPIE 2344, Intelligent Vehicle Highway Systems, (1995).

[3] Joseph R. Morris, Improving Road Safety in Developing Countries, Transportation Research Board, Washington, D.C., 2006.

[4] Standard Specifications for Roads and Structures, North Carolina, Department of Transportation Raleigh, 2012.

[5] Fulweiler W.H., The Development Of Modern Road Surfaces, VoL., 90,9 No. 3, 155183, 1999.

[6] Benvegnu T., Plusquellec D., Lemiègre L., Surfactants from Renewable Sources: Synthesis and Applications, Monomers, Polymers and Composites from Renewable Resources, 2008.

[7] Pasilo counseling engineers, http://scipost.wikipg.com/wiki.

[8] American Association of State Highway and Transportation Officials, 444 N Capitol St. NW Suite 249 - Washington, DC 20001, 2015.

[9] America Metrology Organization, www.bestplaces.net/climatice

[10] Iran Transportation Organization www. tto.ir 
[11] Seyed Mahdi Nasimfar, "Modeling of the weather factors effect on furnish performance in different areas in Iran", M.A thesis, Faculty of Civil Engineering, Sharif Industrial University, 2008.
[12] Iran roads asphalt furnish regulation, Journal of 234, Technical affairs and Criteria codification office, Iran Management and Planning Organization, 2002. 